\title{
BOMB CARBON AS A TRACER OF DIETARY CARBON SOURCES IN OMNIVOROUS MAMMALS
}

\author{
Nancy Beavan-Athfield • Rodger J Sparks \\ Rafter Radiocarbon Laboratory, Institute of Geological and Nuclear Sciences, PO Box 31-312, Lower Hutt, New Zealand. \\ Email: n.beavan@gns.cri.nz.
}

\begin{abstract}
We have isolated amino acid groups from modern bone hydrolysates and compared their relative $\Delta^{14} \mathrm{C}$ value to assess the carbon contribution of diet to the overall radiocarbon signal in bone. We find that both essential and non-essential amino acids may produce widely varying ${ }^{14} \mathrm{C}$, relative to other amino acid groups in the hydrolysate and to the original whole bone protein. We hypothesize that the ${ }^{14} \mathrm{C}$ variations in non-essential amino acids may be due to metabolic effects that utilize essential amino acid carbon skeletons in the creation of non-essential amino acids.
\end{abstract}

\section{INTRODUCTION}

We report on the comparison of the carbon isotope values in bone gelatin and its constituent amino acids, an aspect of our larger project to examine the feeding ecology of the Pacific rat, Rattus exulans, on offshore islands in New Zealand (Beavan and Sparks 1998). For this study of modern populations, we have used the bomb-generated ${ }^{14} \mathrm{C}$ signature.

We chose bomb carbon ${ }^{14} \mathrm{C}$ to track modern diet based on the concept of Broecker and Walton (1959), Nydal et al. (1971) and others. We use $\Delta{ }^{14} \mathrm{C}$, which is the deviation of the ${ }^{14} \mathrm{C}$ concentration from the absolute ${ }^{14} \mathrm{C}$ standard, 0.95 times the activity of the HOxI oxalic acid standard, corrected for isotopic fractionation and decay since 1950 (Stuiver and Polach 1977). Naturally produced atmospheric values of $\Delta^{14} \mathrm{C}$ were substantially increased by testing of nuclear devices in the 1950s and early 1960s, and rose, in the Southern Hemisphere, to approximately $700 \%$ at the height of bomb testing (Manning et al. 1990; Figure 1). Inorganic ${ }^{14} \mathrm{CO}_{2}$ is incorporated into the biosphere via two pathways: by plant photosynthesis into the terrestrial food web, or by atmospheric ${ }^{14} \mathrm{CO}_{2}$ mixing with the surface ocean, which also mixes with upwelling deep water depleted in ${ }^{14} \mathrm{C}$. The latter process results in surfaceocean bicarbonate depletion in ${ }^{14} \mathrm{C}$, relative to atmosphere. Since the atmospheric test ban, $\Delta^{14} \mathrm{C}$ levels have decreased at about $5.5 \%$ per annum, mainly due to anthropogenic $\mathrm{CO}_{2}$ emissions from fossil fuels and mixing between atmosphere and ocean. We use both the annual depletion in the terrestrial environment and the known terrestrial/marine radiocarbon difference to infer the sources of carbon and diet inclusions of the end member studied here, Rattus exulans.

The rat $R$. exulans has an average lifespan of two years and a terrestrial diet of invertebrate species and grass seed, plant shoots and fruit (Fuller 1994; Bunn and Craig 1989). R. exulans has also been implicated as a predator on chicks and eggs of seabirds and some terrestrial birds (Craig 1986; Booth et al. 1996). Both its short lifespan and omnivorous diet make $R$. exulans an appropriate animal to study diet using $\Delta^{14} \mathrm{C}$ variations.

We use the "bomb pulse" ${ }^{14} \mathrm{C}$ to provide supplemental information on probable diet which stable isotope analysis alone does not clearly signal. Although stable isotope analysis is a well-established method of investigating food webs in both modern ecology and in paleodietary studies, a mixed diet can make tissue ${ }^{13} \mathrm{C}$ poorly correlated to the whole-diet signal when isotopic values of dietary components are significantly different (Ambrose and Norr 1993.) We have previously shown that ${ }^{13} \mathrm{C},{ }^{15} \mathrm{~N}$ and ${ }^{14} \mathrm{C}$ variations in various food items in a $R$. exulans natural diet were associated with ${ }^{14} \mathrm{C}$ variations in R. exulans bone. However, in those rat specimens where depleted ${ }^{14} \mathrm{C}$ values indicated a diet with an older carbon reservoir inclusion, such as marine foods, ${ }^{13} \mathrm{C}$ values rat bone were in the range of a terrestrial based diet (Beavan and Sparks 1998).

(C) 2001 by the Arizona Board of Regents on behalf of the University of Arizona RADIOCARBON, Vol 43, Nr 2B, 2001, p 711-721

Proceedings of the 17th International ${ }^{14} \mathrm{C}$ Conference, edited by I Carmi and E Boaretto 


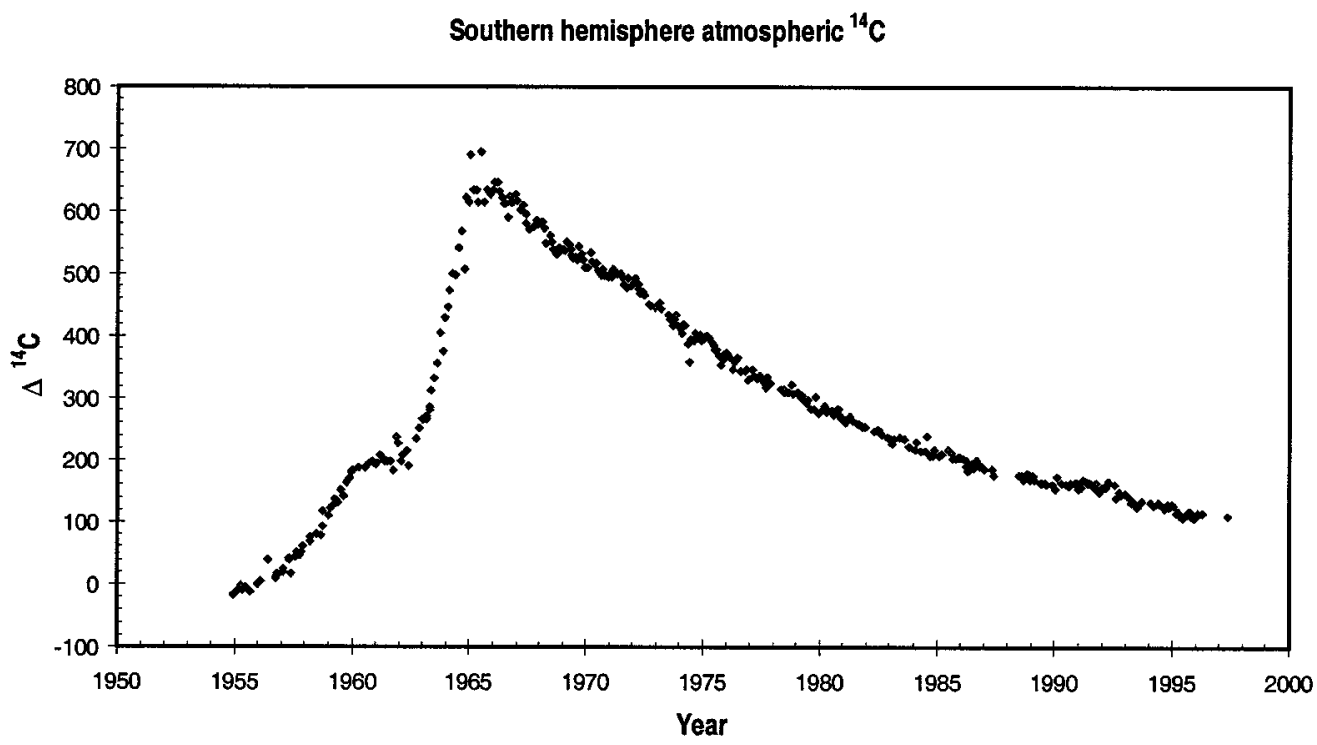

Figure 1 Atmospheric $\mathrm{CO}_{2} \Delta^{14} \mathrm{C}$ data measured at Wellington, New Zealand, $41.3^{\circ} \mathrm{S}, 174.8^{\circ} \mathrm{E}$ (Manning et al. 1990). Additional data by Manning and Sparks (personal communication 1999).

The samples in work presented here include a modern cow (a fairly mono-isotopic, C3-carbon diet) and the Third International Radiocarbon Intercomparison (TIRI) whalebone, a North Atlantic specimen of ancient age (Gulliksen and Scott 1995), to test background in the amino acid separation method. We also compare the $\Delta^{14} \mathrm{C}$ and ${ }^{13} \mathrm{C}$ between bone gelatin and the hydrolysate to check sample preparation methods and to determine if hydrolysis caused significant changes to carbon isotope ratios.

We isolate amino acid groups from bone protein in three $R$. exulans and compare the ${ }^{14} \mathrm{C}$ values in these fractions to observe how groups of essential and non-essential amino acids contribute ${ }^{14} \mathrm{C}$ to the bone gelatin isotope signature of the animal. Each of the three $R$. exulans is treated as an individual, not to be inter-compared, as each rat would have fed individually and opportunistically in the wild.

\section{METHODS}

Specimens of $R$. exulans were collected by snap-trapping in 1998 on Taranga Island $\left(35^{\circ} 58^{\prime} \mathrm{S}, 174^{\circ}\right.$ $43^{\prime} \mathrm{E}$ ) in the method previously described in Beavan and Sparks (1998). Cow bone was obtained in 1990 from a butcher's stock and sampled from a Rafter Laboratory frozen whole-bone archive. TIRI whalebone came from an archive of the TIRI samples.

\section{Physical and Chemical Preparation of Bone Samples}

R. exulans bone and cow bone were defleshed, freeze dried, and scraped to remove cartilage and bone marrow. Bones were sonicated in deionized water, and dried in a vacuum oven at $30{ }^{\circ} \mathrm{C}$. TIRI whalebone was physically cleaned and pulverized to $600-\mu \mathrm{m}$ size. Rat and cow bone were pulverized in a Retch mill to $<450 \mu \mathrm{m}$. Bones were demineralized in $0.5 \mathrm{M} \mathrm{HCl}$ while stirred at room temperature for $1 \mathrm{hr}$. Collagen was filtered from the solution and gelatinized with $0.01 \mathrm{M} \mathrm{HCl}$ in a nitrogen atmosphere at $90{ }^{\circ} \mathrm{C}$ for $16 \mathrm{hr}$. Gelatin was double-filtered through Whatman ${ }^{\mathrm{TM}} \mathrm{GF}$ filters and $0.45 \mu \mathrm{m}$ Acrodisc ${ }^{\mathrm{TM}}$ filters, and lyophilized to weigh yields. An average of $4 \mathrm{mg}$ of gelatin was com- 
busted for each sample, the $\mathrm{CO}_{2}$ cryogenically distilled and graphitized for an accelerator mass spectrometry (AMS) target. A portion of the gelatin was hydrolyzed in 6M HCL in a sealed tube under inert atmosphere at $100^{\circ} \mathrm{C}$ for $20 \mathrm{hr}$, double filtered with Whatman ${ }^{\mathrm{TM}} \mathrm{GF}$ filters and $0.45 \mu \mathrm{m}$ Acrodisc filters. The hydrolysate is used for amino acid separation as described below.

\section{Amino Acid Separation}

A Fast Protein Liquid Chromatography (FPLC) method was used to isolate amino acid groups in bone protein hydrolysates. The primary author developed a separation method using two Pharmacia P500 pumps with inert plumbing and a Pharmacia LCC-500 controller. The FPLC column medium was $5 \mu$ Aminex A-9 resin (Bio-Rad) heated to $55^{\circ} \mathrm{C}$, with flow $0.2 \mathrm{ml} / \mathrm{min}$. Mobile phases were Solution "A": $60 \%$ acetonitrile $\left(\mathrm{CH}_{3} \mathrm{CN}\right)$ and deionized $\mathrm{H}_{2} \mathrm{O}$; Solution "B": $5 \mathrm{M} \mathrm{HCl}$, with concentration percent of Solution B starting at 5\% to run to $100 \%$ over 150 minutes, in $10 \%$ increases. Injection size was $2 \mathrm{ml}$, an approximately $4 \mathrm{mg}$ concentration of bone hydrolysate at $0.25 \mathrm{M} \mathrm{HCl}$. Each bone hydrolysate had at least six chromatographic runs to derive sufficient carbon in amino acid separations for AMS target preparation. Elutions were detected at UV 214, collected and lyophilized to remove $\mathrm{CH}_{3} \mathrm{CN}$ and $\mathrm{HCl}$ residue, then prepared for AMS and stable isotope analysis as per Beavan and Sparks (1998). Amino groups were analytically determined in subsamples of each elution by PITC derivitization and analysis by narrow-bore RP-APLC (Hubbard 1995) at the University of Otago's Protein Microchemistry Facilty.

\section{$\delta^{13} \mathrm{C}$ Analysis}

Samples for $\delta^{13} \mathrm{C}$ were analyzed on a Europa Geo 20/20, interfaced to an ANCA-SL elemental analyzer in continuous flow mode. Isotopes were analyzed simultaneously from an average $1.5 \mathrm{mg}$ of bone protein. The $\mathrm{CO}_{2}$ is resolved using chromatographic separation on a GC column at $85^{\circ} \mathrm{C}$, and analyzed for percent abundance and delta element value. Analysis of each sample was done in duplicate; reported values are drift-corrected and an average of the duplicate. Machine error is $\pm 0.1 \%$ for carbon. Standards used were flour $\left({ }^{13} \mathrm{C}-25.3 \%\right.$ ), and ANU sucrose $\left({ }^{13} \mathrm{C}-10.4 \%\right.$ ) which were run after every six duplicates of sample. For ${ }^{14} \mathrm{C}$ calibration on combusted material, we analyzed ${ }^{13} \mathrm{C}$ for sample $\mathrm{CO}_{2}$ on a NAA 6-60 RMS mass spectrometer, with machine error $\pm 0.1 \%$.

\section{RESULTS}

\section{Background Test I}

Modern cow bone (date of death 1990) was selected to check contamination from the separation method. In Table 1, the mean of two bone gelatin analyses is $\Delta^{14} \mathrm{C}=236 \pm 1.3 \%$, SD 2.3. Between gelatinization and hydrolysis we see a shift in $\Delta^{14} \mathrm{C}$ of $+95.3 \%$ (Table 2). The replication of ${ }^{14} \mathrm{C}$ values for nonessential and essential amino acids (NZA 9691, 9692) would be expected for a herbivore on a monoisotopic diet. Both non-essential and essential elutions are equal to the atmospheric ${ }^{14} \mathrm{C}$ of around 1973 (approx. $+430 \%$, Manning et al. 1990). Given its year of death, we might expect ${ }^{14} \mathrm{C}$ of this animal to be nearer to Southern Hemisphere atmospheric values of 1990 levels of a mean of +160 $\pm 4 \%$. Some offsets to higher ${ }^{14} \mathrm{C}$ may be contributed by the age of the cow at death, the food stock ${ }^{14} \mathrm{C}$ signal, and the rate of carbon turnover in bone of an adult animal, but the magnitude of the observed difference is considerable. We do not believe that either the chemical processing or the FPLC separation process itself was contaminated with bomb carbon, based on our second background test on TIRI Whalebone. 
Table 1 Percent carbon, $\delta^{13} \mathrm{C}$, and $\Delta^{14} \mathrm{C}$ of amino acid fractions in modern cow bone. Amino acid percentages in a typical collagen profile (33\% Gly, $22 \%$ Pro, and HPro, $11 \%$ Ala) shift with hydrolysis (18\% Gly, 50\% Pro-HPro, 6\% Ala). The $\Delta^{14} \mathrm{C}$ values of essential and nonessential amino acids were similar, as would be expected for a herbivore whose protein/essential amino acid intake is based on a diet of vegetation.

\begin{tabular}{llllll}
\hline & & & & \multicolumn{2}{l}{ Lab code } \\
Modern cow bone & Amino acids & $\% \mathrm{C}$ & $\delta^{13} \mathrm{C} \% 0$ & $\Delta^{14} \mathrm{C} \% 0$ & NZA- \\
\hline Bone gelatin (N=2) & Collagen profile & 42 & -22.2 & $236.0 \pm 1.3$ & 7121,7122 \\
$\begin{array}{l}\text { Bone hydrolysate for } \\
\text { FPLC separation }\end{array}$ & Hydrolysate profile & 30 & -22.4 & $331.3 \pm 9.4$ & 9585 \\
Non-essential aminos & Gly (84\%) Tyr (16\%) & 45.5 & -23.4 & $435 \pm 10$ & 9691 \\
Essential aminos & Arg/lle/Leu/Phe (98\%) & 70 & -22.1 & $435 \pm 10$ & 9692 \\
\hline
\end{tabular}

Table 2 Percent carbon, $\delta^{13} \mathrm{C}$ and $\Delta^{14} \mathrm{C}$ of amino acid fractions in TIRI whalebone. Conventional Radiocarbon Age (CRA) dates for gelatin and hydrolysate of whole compare well with the international consensus value. Amino acids in the elution TA46/4 returns its hydrolysate split CRA within error, but a reproducible depletion of $1668 \pm 57 \mathrm{BP}$ occurs in two elutions of similar non-essential amino acid groups (Asp/Pro-HPro/Ala) in TA46/3 and TB37/4.

\begin{tabular}{|c|c|c|c|c|c|}
\hline TIRI whalebone & Amino acids & $\% \mathrm{C}$ & $\delta^{13} \mathrm{C} \%$ & CRA (BP) & $\begin{array}{l}\text { Lab code } \\
\text { NZA- }\end{array}$ \\
\hline $\begin{array}{l}\text { Bone gelatin } \\
\text { International Consensus value } \\
\text { (Gulliksen and Scott 1995) }\end{array}$ & NA & $\mathrm{Nd}$ & -15.1 & $12,788 \pm 30$ & N/A \\
\hline $\begin{array}{l}\text { Bone gelatin mean, } \\
\text { processed at Rafter Lab } \\
(\mathrm{N}=12)\end{array}$ & Collagen profile & 45 & -14.2 & $12,660 \pm 60$ & Multiple \\
\hline $\begin{array}{l}\text { Bone hydrolyzate } \\
\text { TA split } \\
\text { TB split } \\
\text { Insoluble residue }\end{array}$ & Hydrolysate profile & $\begin{array}{l}52 \\
52 \\
14\end{array}$ & $\begin{array}{l}-14.2 \\
-14.2 \\
-18.8\end{array}$ & $\begin{array}{l}12,530 \pm 80 \\
12,754 \pm 74 \\
10,230 \pm 95\end{array}$ & $\begin{array}{l}10310 \\
10216 \\
11047\end{array}$ \\
\hline Elution TA46/3 & $\begin{array}{l}\text { Asp }(26.7 \%) \\
\text { Pro-HPro }(62.2 \%) \\
\text { Ala }(11.1 \%)\end{array}$ & 44 & -17.9 & $11,363 \pm 118$ & 10311 \\
\hline Elution TA46/4 & $\begin{array}{l}\text { Gly }(43.9 \%) \\
\text { Pro-HPro }(26.5 \%) \\
\text { Ala }(10.6 \%)\end{array}$ & 73 & -14.2 & $12,450 \pm 80$ & 10312 \\
\hline Elution TB37/4 & $\begin{array}{l}\text { Asp }(32.4 \%) \\
\text { Pro-HPro }(39 \%) \\
\text { Ala }(41.1 \%)\end{array}$ & 53 & -18.2 & $11,120 \pm 80$ & 10313 \\
\hline
\end{tabular}

\section{Background Test II}

To check whether the FPLC-method contributes modern ${ }^{14} \mathrm{C}$ background, we analyzed a hydrolysate of ancient whalebone from the Third International Radiocarbon Intercomparison (TIRI) (Gulliksen and Scott 1995), reported as a planktonic feeding species (M Scott, personal communication 1999). For this ancient bone, we compare the Conventional Radiocarbon Ages (CRA), expressed in years before present, rather than $\Delta^{14} \mathrm{C} \%$ values used for modern samples.

Whalebone gelatin CRA dates and direct hydrolysates of bone protein (Table 2) compare well with the international consensus value of 12,788 \pm 30 BP from TIRI (Gulliksen and Scott 1995). Results 
from gelatin and hydrolysate indicate no contamination of the sample with bomb carbon during chemical preparation of the bone for either AMS analysis or amino acid separation. In the amino acid groups eluted from this hydrolysate, TA46/4 returns a CRA similar to its hydrolysate split value within measurement error. An interesting and reproducible depletion of $1668 \pm 57{ }^{14} \mathrm{C}$ yr relative to the TIRI consensus value occurs in two elutions of similar non-essential amino acid groups (Asp/ Pro-HPro/Ala) in TA46/3 and TB37/4 (NZA 10311, 10313). Explanation of the Asp/Pro-Hpro/Ala shift in terms of contamination with bomb carbon from modern materials or enriched contamination from the laboratory environment is not likely because the effect is reproducible, and is accompanied by a systematic shift in $\delta^{13} \mathrm{C}$. Secondly, a systematic shift in ${ }^{14} \mathrm{C}$ by the chromatography is unlikely because of the difference in magnitude between the radiocarbon shift in the cow and whalebone.

\section{Sources of the Carbon Signature in Rat Diet}

Table 3 lists isotope values for modern $R$. exulans from two islands off the coast of New Zealand and a variety of foods that the rats scavenge (Beavan and Sparks 1998 and additional data from 1998 collection on Taranga Island, NZ).

Table 3 Animal foods ingested by $R$. exulans have ${ }^{14} \mathrm{C}$ values are not in equilibrium with contemporary atmospheric values of ${ }^{14} \mathrm{C}$ in $1996-1998$, the period of collection. There appears to be a trophic level transfer of radiocarbon through the terrestrial food chain, while marine-sourced foods provide depleted ${ }^{14} \mathrm{C}$. The mean $\delta^{15} \mathrm{~N},{ }^{13} \mathrm{C}$ and $\Delta{ }^{14} \mathrm{C}$ values for $R$. exulans from Taranga and Kapiti Islands imply omnivorous diets that result from a mix of isotope values of many possible diet items. Samples from Taranga Island from unpublished data of Beavan, Kapiti Island data from Beavan and Sparks (1998).

\begin{tabular}{|c|c|c|c|c|}
\hline \multirow{2}{*}{$\begin{array}{l}\text { Atmospheric }{ }^{14} C \\
1996-1998(\mathrm{~N}=5)\end{array}$} & & & $\Delta^{14} \mathrm{C} \%$ o & \multirow[b]{3}{*}{$\Delta^{14} \mathrm{C} \%$} \\
\hline & $\begin{array}{l}\text { Mean } \\
\text { SD }\end{array}$ & & $\begin{array}{l}111.7 \pm 1.1 \\
2.5\end{array}$ & \\
\hline \multirow[t]{2}{*}{ Terrestrial Vegetation $(\mathrm{N}=13)$} & & & $\delta^{13} \mathrm{C} \%$ & \\
\hline & $\begin{array}{l}\text { Mean } \\
\text { SD }\end{array}$ & & $\begin{array}{l}-29.4 \pm 0.8 \\
2.85\end{array}$ & $\begin{array}{l}111.7 \pm 2.8 \\
10.2\end{array}$ \\
\hline Terrestrial Invertebrates & & $\delta^{15} \mathrm{~N} \% o$ & $\delta^{13} \mathrm{C} \%$ & $\Delta^{14} \mathrm{C} \%$ \\
\hline Detritus feeders $(\mathrm{N}=7)$ & $\begin{array}{l}\text { Mean } \\
\text { SD }\end{array}$ & $\begin{array}{c}4.1 \pm 1.6 \\
3.6\end{array}$ & $\begin{array}{l}-26.0 \pm 0.5 \\
1.4\end{array}$ & $\begin{array}{l}115.6 \pm 3.7 \\
9.9\end{array}$ \\
\hline Vegetation feeders $(\mathrm{N}=2)$ & $\begin{array}{l}\text { Mean } \\
\text { SD }\end{array}$ & $\begin{array}{l}5.5 \pm 1.4 \\
2.0\end{array}$ & $\begin{array}{l}-25.1 \pm .85 \\
1.2\end{array}$ & $\begin{array}{c}116.9 \pm 17.7 \\
24.9\end{array}$ \\
\hline Carnivores $(\mathrm{N}=4)$ & $\begin{array}{l}\text { Mean } \\
\text { SD }\end{array}$ & $\begin{array}{l}8.9 \pm 1.7 \\
3.02\end{array}$ & $\begin{array}{l}-25.3 \pm 0.6 \\
1.2\end{array}$ & $\begin{array}{l}151.6 \pm 13.1 \\
26.2\end{array}$ \\
\hline \multicolumn{3}{|l|}{$\begin{array}{l}\text { Mean shallow seawater values } \\
\quad \text { Taranga Island (November 1998) }(\mathrm{N}=7)\end{array}$} & $+0.7 \pm 0.1$ & $70.7 \pm 2.8$ \\
\hline $\begin{array}{l}\text { Marine vertebrates } \\
\quad \text { Seabirds, fish }(\mathrm{N}=4)\end{array}$ & $\begin{array}{l}\text { Mean } \\
\text { SD }\end{array}$ & $\begin{array}{l}13.1 \pm 0.9 \\
\quad 2.2\end{array}$ & $\begin{array}{l}-18.4 \pm 0.9 \\
\quad 2.04\end{array}$ & $\begin{array}{l}80.2 \pm 3.9 \\
\quad 8.8\end{array}$ \\
\hline $\begin{array}{l}\text { Taranga Island R. exulans } \\
\quad \text { Trapped 1997-1998 (N=14) }\end{array}$ & $\begin{array}{l}\text { Mean } \\
\text { SD }\end{array}$ & $\begin{array}{l}13.2 \pm 0.1 \\
0.07\end{array}$ & $\begin{array}{l}-21.0 \pm 0.7 \\
0.99\end{array}$ & $\begin{array}{l}104.9 \pm 1.3 \\
1.77\end{array}$ \\
\hline $\begin{array}{l}\text { Kapiti Island R. exulans } \\
\text { (Beavan and Sparks 1998) } \\
\text { In Grassland and bush (n=7) }\end{array}$ & $\begin{array}{l}\text { Mean } \\
\text { SD }\end{array}$ & $\begin{array}{l}6.5 \pm 0.9 \\
2.4\end{array}$ & $\begin{array}{c}-21.4 \pm 0.3 \\
0.8\end{array}$ & $\begin{array}{l}131 \pm 3.5 \\
9.4\end{array}$ \\
\hline $\begin{array}{l}\text { In Shearwater (Puffinus griesus) } \\
\text { Nest Colony }(\mathrm{n}=2)\end{array}$ & $\begin{array}{l}\text { Mean } \\
\text { SD }\end{array}$ & $\begin{array}{l}11.5 \pm 0.15 \\
0.2\end{array}$ & $\begin{array}{c}-20.9 \pm 0.3 \\
0.5\end{array}$ & $\begin{array}{c}69 \pm 13 \\
18.5\end{array}$ \\
\hline
\end{tabular}




\section{Rattus exulans Bone}

Gelatin $\Delta{ }^{14} \mathrm{C}$ and ${ }^{13} \mathrm{C}$ for $R$. exulans in Table 4 is in the range for vegetarian and detritus-feeding terrestrial invertebrates (Table 1). After hydrolysis, there is a $+193.7 \%$ increase in ${ }^{14} \mathrm{C}$ relative to the gelatin form. The insoluble residue filtered from hydrolyzed protein has a significantly low ${ }^{14} \mathrm{C}$ depletion, and a ${ }^{13} \mathrm{C}$ depletion of $-6.5 \%$ relative to the hydrolysate itself. Insoluble material includes sugars and other non-collagenous material precipitated in Maillard reactions during hydrolysis, which are removed during filtering of the free-amino mixture prior to injection on the chromatography column.

Table 4 Percent carbon, $\delta^{13} \mathrm{C}$, and $\Delta^{14} \mathrm{C}$ of protein and amino acid fractions for $R$. exulans $\mathrm{T} 11 \mathrm{cld} 3$. Whole bone gelatin $\Delta^{14} \mathrm{C}$ and ${ }^{13} \mathrm{C}$ values are similar to those for vegetation and detritus/plant-feeding terrestrial invertebrates. In FPLC-separations, both essential and non-essential amino groups are depleted in ${ }^{14} \mathrm{C}$ and varied in $\delta^{13} \mathrm{C}$ relative to bone gelatin.

\begin{tabular}{|c|c|c|c|c|c|}
\hline R. exulans $\mathrm{T} 11 \mathrm{cld} 3$ & Amino acids & $\% \mathrm{C}$ & $\delta^{13} \mathrm{C} \% o$ & $\Delta^{14} \mathrm{C} \% o$ & $\begin{array}{l}\text { Lab code } \\
\text { NZA- }\end{array}$ \\
\hline Bone gelatin $(n=2)$ & Collagen profile & 45 & -22.5 & $113.3 \pm 9.8$ & 8347,9168 \\
\hline Insoluble residue from gelatin & NA & 68.9 & -25.5 & $105.2 \pm 8.3$ & 11048 \\
\hline Bone hydrolysate & Hydrolysate profile & 45 & -21.8 & $307.8 \pm 9.4$ & 10361 \\
\hline $\begin{array}{l}\text { Insoluble residue from } \\
\text { hydrolysate }\end{array}$ & N/A & 67.3 & -28.3 & $31.8 \pm 7.8$ & 11051 \\
\hline Predominant non-essentials & $\begin{array}{l}\text { Gly/Pro-Hpro/ } \\
\text { Ala/Ser }(98 \%) \\
\text { Thr/Phe/Ile/Val (2\%) }\end{array}$ & 60 & -18.5 & $87.3 \pm 7.9$ & 10365 \\
\hline Predominant non-essentials & $\begin{array}{l}\text { Gly/Pro-Hpro } \\
\text { /Ala }(95 \%) \\
\text { Val/Leu }(5 \%)\end{array}$ & 49 & -18.5 & $75.5 \pm 7.9$ & 10366 \\
\hline $\begin{array}{l}\text { Aprox. equal amts. essential \& } \\
\text { non-essential }\end{array}$ & $\begin{array}{l}\text { Gly/Pro-Hpro } \\
\text { /Ala/Ser }(48.5 \%) \\
\text { Thr/Phe/Ile/Val } \\
\text { /Met }(51 \%)\end{array}$ & 33 & -24.7 & $87.8 \pm 6.9$ & 10362 \\
\hline $\begin{array}{l}\text { Aprox. equal amts. essential \& } \\
\text { non-essential }\end{array}$ & $\begin{array}{l}\text { Hpro / Ser }(47 \%) \\
\text { Phe /Ile/Val/Met } \\
\text { /Leu }(50 \%)\end{array}$ & 44 & -24.7 & $82.2 \pm 9.0$ & 10364 \\
\hline Predominant essential & $\begin{array}{l}\text { Thr/Val/Met/Ile/ } \\
\text { Leu/Phe (60.5\%) } \\
\text { H-Pro/Ser/Asp (39.5\%) }\end{array}$ & 44 & -24.8 & $66.7 \pm 7.4$ & 10363 \\
\hline
\end{tabular}

An elution with predominant essentials (NZA10363) is the most ${ }^{14} \mathrm{C}$ depleted. While a $\Delta^{14} \mathrm{C}$ depletion can result from marine sourced foods, we note that the $\delta^{13} \mathrm{C}$ value is inconsistent with that expected in a marine range of -17 to $0.7 \%$ (Schoeninger and DeNiro 1984).

In other elution groups both essential and non-essential amino groups are also depleted by $25.5 \%$ o to $46.6 \%$ in ${ }^{14} \mathrm{C}$, relative to the original bone gelatin value. The highest $\Delta^{14} \mathrm{C}$ values occur when amounts of essentials are in equal proportion to non-essentials (NZA10362), and in the largely nonessential grouping (NZA 10365).

In Table 5, R. exulans bone gelatin has ${ }^{14} \mathrm{C}$ near atmospheric levels for the year of collection, and is enriched in ${ }^{13} \mathrm{C}$. As rats are not strictly fresh vegetation consumers as ${ }^{14} \mathrm{C}$ at this level might suggest, and due to enriched ${ }^{13} \mathrm{C}$, we interpret the radiocarbon value of the bone gelatin to be a mix of carbon 
Table 5 Percent carbon, $\delta^{13} \mathrm{C}$, and $\Delta^{14} \mathrm{C}$ of protein and amino acid fractions for $R$. exulans T11cld2. The original bone gelatin ${ }^{14} \mathrm{C}$ and ${ }^{13} \mathrm{C}$ suggests that the diet of this rat has been heavily influenced by marine-sourced foods. Amino acid elutions are all similarly depleted below atmospheric values for 1998 year of collection (see Table 3), except for NZA10026 and NZA9965

\begin{tabular}{|c|c|c|c|c|c|}
\hline R. exulans T11cld 2 & Amino acids & $\% \mathrm{C}$ & $\delta^{13} \mathrm{C} \%$ & $\Delta^{14} \mathrm{C} \%$ o & $\begin{array}{l}\text { Lab code } \\
\text { NZA- }\end{array}$ \\
\hline Bone gelatin $(n=2)$ & Collagen profile & 43 & -15.7 & $97.3 \pm 9.7$ & 8346,9354 \\
\hline Bone hydrolysate & Hydrolysate profile & 48 & -14.0 & $108.9 \pm 8.4$ & 11049 \\
\hline $\begin{array}{l}\text { Predominant } \\
\text { Non-essentials }\end{array}$ & $\begin{array}{l}\text { Pro }(55.9 \%) \text { Tyr }(14.8 \%) \\
\text { His/Lys/Leu/Met/Thr/Val } \\
(29.3 \%)\end{array}$ & 64 & -16.7 & $136.7 \pm 7.9$ & 10026 \\
\hline Non-essentials & Ala $(86.8 \%)$ Tyr (13.2\%) & 70 & -17.1 & $115.2 \pm 8.3$ & 9965 \\
\hline Non-essentials & $\begin{array}{l}\text { Gly }(59.4 \%) \text { Pro }(39.5 \%) \\
\operatorname{Tyr}(1.1 \%)\end{array}$ & 70 & -10.3 & $73.7 \pm 7.6$ & 10022 \\
\hline Non-essentials & $\begin{array}{l}\text { Gly }(59.5 \%) \text { Pro }(39.3 \%) \\
\text { Tyr }(1.2 \%)\end{array}$ & 69 & -10.3 & $59.2 \pm 7.4$ & 9966 \\
\hline Non-essentials & $\begin{array}{l}\text { Gly }(58.8 \%) \text { Pro }(39.4 \%) \\
\text { Tyr }(1.8 \%)\end{array}$ & 69 & -10.6 & $52.0 \pm 7.2$ & 9967 \\
\hline Predominant essentials & $\begin{array}{l}\text { Leu/Met/Phe/Thr/Val (71\%) } \\
\text { Ser/Tyr (29) }\end{array}$ & 70 & -17.4 & $55.3 \pm 7.3$ & 9970 \\
\hline Predominant essentials & $\begin{array}{l}\text { Leu/Met/Phe/Thr/Val }(73.4 \%) \\
\text { Ser/Tyr }(26.6 \%)\end{array}$ & 70 & -17.3 & $56.2 \pm 7.6$ & 10021 \\
\hline
\end{tabular}

Table 6 Percent carbon, $\delta^{13} \mathrm{C}$, and $\Delta^{14} \mathrm{C}$ of protein and amino acid fractions for $R$. exulans T12cld1. $\Delta^{14} \mathrm{C}$ values among FPLC-separated amino groups varied significantly from the original whole bone gelatin value. Essential amino acids (histadine, lysine, isoleucene, leucine, threonine) appear to contribute lower values of ${ }^{14} \mathrm{C}$. NZA9964 is non-essentials are unusually high, yet still within the peak values of bomb carbon ${ }^{14} \mathrm{C}$.

\begin{tabular}{|c|c|c|c|c|c|}
\hline R. exulans T12cld1 & Amino acids & $\% \mathrm{C}$ & $\delta^{13} \mathrm{C} \%$ & $\Delta^{14} \mathrm{C} \%$ & $\begin{array}{l}\text { Lab code } \\
\text { NZA- }\end{array}$ \\
\hline Bone gelatin $(\mathrm{N}=2)$ & Collagen profile & 48 & -21.4 & $138 \pm 9.0$ & 9166,8345 \\
\hline Bone hydrolysate & Hydrolysate profile & 45 & -21.7 & $84 \pm 8.2$ & 11046 \\
\hline $\begin{array}{l}\text { Equal amts. essential and } \\
\text { nonessential }\end{array}$ & $\begin{array}{l}\text { Hist/Lys/Ile/ } \\
\text { Leu/Thr(51/1\%) } \\
\text { Ser/Tyr (48.9\%) }\end{array}$ & 53 & -25.4 & $44.2 \pm 7.2$ & 9963 \\
\hline Nonessential & $\begin{array}{l}\text { Gly }(51.7 \%) \\
\text { Pro }(35.9 \%) \\
\text { Tyr }(12.4 \%)\end{array}$ & 52 & -18.2 & $668 \pm 12$ & 9964 \\
\hline Predominant nonessential & $\begin{array}{l}\text { Gly }(11 \%) \\
\text { Pro }(15.2 \%) \\
\text { Tyr }(37 \%) \\
\text { Ala }(27.8 \%) \\
\text { Hist/Lys }(9.1 \%)\end{array}$ & 61 & -22.0 & $153.7 \pm 8.0$ & 10023 \\
\hline
\end{tabular}


from both terrestrial items and marine-sourced foods. In these elutions, both non-essential and essential amino acids carry depleted ${ }^{14} \mathrm{C}$. Duplicated elutions of non-essential groups (NZA10022, 9966, 9967) have ${ }^{14} \mathrm{C}$ values similar to duplicated elutions of predominantly essential amino acids (NZA10021, 9970), with the ${ }^{13} \mathrm{C}$ of the former mixture enriched by about $7 \%$.

In Table 6 , R. exulans bone gelatin $\Delta^{14} \mathrm{C}(\mathrm{NZA} 8345,9166)$ and ${ }^{13} \mathrm{C}$ values are in the isotopic range of the vegetarian or detritus-feeding terrestrial invertebrates in Table 1, implying a diet comprised largely of these items. After hydrolysis, bone protein $\Delta{ }^{14} \mathrm{C}$ is depleted by $54 \%$ relative to bone gelatin value (NZA11046).

The ${ }^{14} \mathrm{C}$ values of the amino groups also vary appreciably from the hydrolysate value. An equal amount of essential and non-essential amino acids produce the most depleted ${ }^{14} \mathrm{C}(44.2 \pm 7.2 \%$, NZA 9963), and an elution of non-essential amino acids (Gly/Pro/Tyr) contributes the highest value $\left({ }^{14} \mathrm{C}=668 \pm 12 \%\right.$ o, NZA 9964). The latter is equivalent to the maximum ${ }^{14} \mathrm{C}$ at the peak of the Southern Hemisphere bomb carbon curve (Manning et al. 1990). In previous work (Beavan and Sparks 1998), we found ${ }^{14} \mathrm{C}$ in common earthworms sampled in 1997 of up to ${ }^{14} \mathrm{C}=+229 \%$, due to ingestion of leaf mould and organic debris carrying carbon from previous years' photosynthesis. However, on Taranga Island we had not recorded ${ }^{14} \mathrm{C}$ values as high in our limited sampling of food items from the site, and we reserve comment on the value as an indication of a dietary sourced carbon. We note that the carbon yield in combustion does not indicate that this fraction was significantly different from other fractions, and the measured ${ }^{13} \mathrm{C}=-18.2 \%$ further suggests that the composition did not include unusual or inorganic sources of carbon.

By comparison, NZA 10023 has lower percentages of Gly and Pro, higher Tyr, and the addition of Ala, plus essential amino acids (9.1\% His/Lys), resulting in a ${ }^{14} \mathrm{C}$ value which is depleted with respect to the previous non-essential amino elution, to ${ }^{14} \mathrm{C}=153.7 \pm 8 \%$.

\section{DISCUSSION}

Due to the omnivorous diets of $R$. exulans, their bone protein $\delta^{13} \mathrm{C}$ and $\Delta^{14} \mathrm{C}$ values result from a mix of many possible diet items. Biochemical fractions and tissues retain an isotopic memory of carbon in food at the time of synthesis, which is moderated by different rates of tissue turnover (Tieszen et al. 1983). Carbon from dietary protein is transferred in part through essential amino acids, which strongly influence the ${ }^{13} \mathrm{C}$ signature of tissue synthesized from these components (Ambrose and Norr 1993) and necessarily also transfer ${ }^{14} \mathrm{C}$. We have shown that ${ }^{14} \mathrm{C}$ increases through trophic levels relative to the ${ }^{14} \mathrm{C}$ atmospheric values at the period of collection (Table 1), demonstrating a "food chain" effect transfer of carbon through feeding echelons. Unlike the fractionation effects upon stable isotopes in a food chain, ${ }^{14} \mathrm{C}$ levels above atmospheric are a function of time lags between initial photosynthesis and the time that vegetation was ingested by invertebrates, etc., and so on along a food chain.

Analysis of different components in bone protein (gelatin, insoluble residues, hydrolysates, and essential and non-essential amino acid groups) suggests that variable $\Delta^{14} \mathrm{C}$ and ${ }^{13} \mathrm{C}$ values in the components of a material commonly thought of as homogeneous carry distinct carbon isotopic values. Of note is that essential and non-essential amino acids produce widely varying values of ${ }^{14} \mathrm{C}$, relative to each other and to unseparated bone protein.

The differences in ${ }^{13} \mathrm{C}$ seen among the amino acid separations could be due to the characteristic ${ }^{13} \mathrm{C}$ range in individual amino acids which is associated with their biochemical pathways or fractionation between dietary protein source and collagen metabolism (Macko et al. 1987; Hare et al. 1991). For 
${ }^{14} \mathrm{C}$, the variation among separations is predominantly a mixing effect of ${ }^{14} \mathrm{C}$ from different amino acids synthesized from different carbon reservoirs.

Our original assumption was that, in an omnivore diet, only essential amino acids would show $\Delta^{14} \mathrm{C}$ variation, as they are contributed from a variety of foods and carbon reservoirs. However, we have shown that certain non-essential amino acids also show this effect, raising the question: have essential amino acids contributed to the synthesis of non-essential amino acids?

The routing of dietary carbon to bone protein is largely via the essential amino acids (Ambrose and Norr 1993). During seasonal dietary shifts or at different stages in a rat's life cycle, rat diet could contain essential amino acids in excess of nutritional requirements. Obled et al. (1983) found that the demand for essential amino acids for protein metabolism was age-dependent, with juvenile rats having a faster protein turnover rate and a fast catabolic rate for amino acids. Garlick et al. (1999) also found that high protein feeding initially results in protein retention and a greater recycling of body protein in response to meals. Tanaka et al. (1991) showed that in high protein diets, essential amino acids are not conserved for tissue metabolism, but may join the general metabolic pool.

The Krebs and Embden Meyerhoff pathways provide the biochemical mechanisms by which excess dietary amino acids can contribute carbon to non-essential amino acid synthesis (Figure 2). These processes provide pathways for the creation of the non-essential amino acids Glycine, Serine, Proline, and Alanine, among others (Bettelheim and March 1998; Yudkin and Offord 1973; Lehninger 1982).

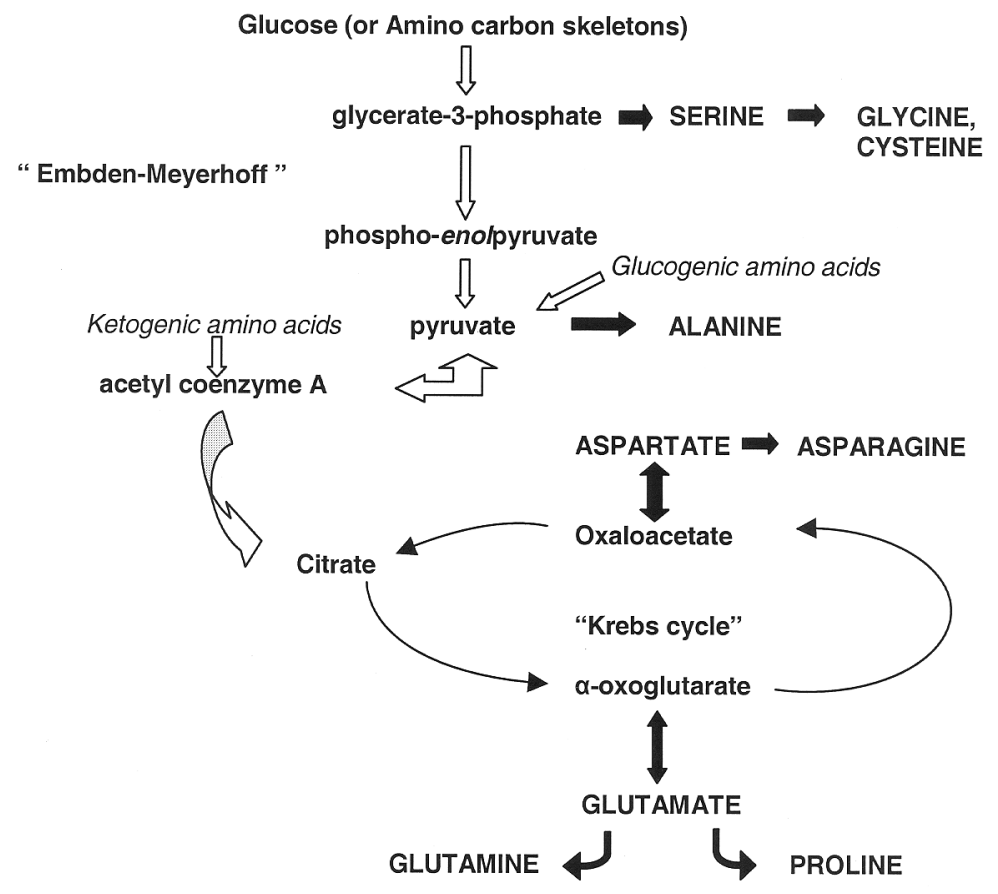

Figure 2 Embden-Meyerhoff pathway and Krebs cycle, from which some nonessential amino acids are metabolized. If the carbon skeleton of an essential amino acid is available to be catabolized to pyruvate, a pathway exists for essential amino acid $\Delta^{14} \mathrm{C}$ signature to be lent to substrates that later build amino acids. Modified from Yudkin and Offord (1973:382). 
These four non-essential amino acids, in variable percent mixtures, and with other non-essential aminos, have appeared in several of our elutions with variable radiocarbon values. As our current work was developed from material used to study natural populations of $R$. exulans and their feeding ecology, we acknowledge the obvious limitations in our sampling for this application. If we are to examine further this hypothesis of dietary carbon transfer to non-essential amino acid synthesis, laboratory rat populations and controlled diet experiments with labeled amino acids are required.

\section{CONCLUSIONS}

Despite the limitations to our sample set, three conclusions follow from the study of ${ }^{14} \mathrm{C}$ in bone protein fractions:

1. Background checks with modern cow bone and TIRI whalebone show that hydrolysis does appear to alter the typical amino acid profile of bone gelatin, and the $\Delta^{14} \mathrm{C}$ ratio of the hydrolysate can differ significantly from the original bone protein. This may be due to the filtering out of insoluble residues consisting of lipids and other protein fractions with different ${ }^{14} \mathrm{C}$ values.

2. ${ }^{14} \mathrm{C}$ does not appear to be uniformly distributed among components of bone protein in these Rattus specimens, which may be a function of omnivorous diets from multiple carbon reservoirs.

3. The existence of significant ${ }^{14} \mathrm{C}$ differences between components suggests complex transfer of carbon from dietary essential amino acids to non-essential amino acids, and other bone fractions.

The extremes of ${ }^{14} \mathrm{C}$ values observed also suggest that bone protein could be reflecting the mixture of ${ }^{14} \mathrm{C}$ signals spanning a time interval of up to $30-40$ years. This effect is apparent only because of the rapidly changing bomb signal, and would not be easily observable in pre-bomb or older material. To further examine our current conclusions, we plan additional work to determine if there are specific amino acids or predictable patterns to this effect.

\section{ACKNOWLEDGMENTS}

We are grateful for the assistance of D Harding and D Poll, Massey University; John Adams and Bruce McFadgen, New Zealand Department of Conservation; K Rogers, Rafter Lab; and D Carne, Otago University. Research was funded by the Institute of Geological and Nuclear Sciences NSOF.

\section{REFERENCES}

Ambrose SH, Norr L. 1993. Experimental evidence for the relationship of the carbon isotope ratios of whole diet and dietary protein to those of bone collagen and carbonate In: Mabert JB, Grupe G, editors. Prehistoric human bone - archaeology at the molecular level. Berlin: Springer-Verlag. p 1-38.

Beavan NR, Sparks RJ. 1998. Factors influencing ${ }^{14} \mathrm{C}$ ages of the Pacific Rat Rattus exulans. Radiocarbon 40(2):601-13.

Bettelheim FB, March J. 1998. Introduction to general, organic \& biochemistry. 5 th edition. Sydney: Harcourt Brace. p 679.

Booth AM, Minot EO, Fordham RA, Innes JG. 1996. Kiore (Rattus exulans) predation on the eggs of the Little Shearwater (Puffinus assimilis baurakiensis). Notornis 43:147-53.

Broecker WS, Walton A. 1959. Radiocarbon from nuclear tests. Science 130:309-14.

Bunn TJ, Craig JL. 1989. Population cycles of Rattus exulans: population changes, diet, and food availability.
New Zealand Journal of Zoology 16:409-18.

Craig JL. 1986. The effects of kiore on other fauna. In: Wright AE, Beever RE, editors. The offshore islands of northern New Zealand. Wellington: New Zealand Department of Lands and Survey Information 16. p 41925.

Fuller SA. 1994. Biological indexing on Kapiti Island, a preliminary assessment, March-June 1994. Wellington: New Zealand Department of Conservation.

Garlick PJ, McNurlan MA, Patlak CS. 1999. Adaption of protein metabolism in relation to limits to high dietary protein intake. European Journal of Clinical Nutrition. 53(Supplement 1):34-43.

Gulliksen S, Scott M.1995. Report of the TIRI workshop. Radiocarbon 37(2):820-1.

Hare PE, Fogal ML, Stafford TW, Mitchell AD, Hoering TC. 1991. The isotopic composition of carbon and nitrogen in individual amino acids isolated from modern and fossil proteins. Journal of Archaeological Science 18:277-92. 
Hubbard MJ. 1995. Amino acid analysis. European Journal of Biochemistry 230:68-79.

Lehninger AL. 1982 Principles of biochemistry. New York: Worth Publishers. p 545.

Macko SA, Fogal ML, Hare PE, Hoering TC. 1987. Isotopic fractionation of nitrogen and carbon in the synthesis of amino acids by microorganisms. Chemical Geology 65:79-92.

Manning MR, Lowe DC, Melhuish WH, Sparks RJ, Wallace G, Brenninkmeijer CAM, McGill RC. 1990. The use of radiocarbon measurements in atmospheric studies. Radiocarbon 32(1):37-58.

Nydal R, Lovseth K, Syrstad O. 1971. Bomb ${ }^{14} \mathrm{C}$ in the human population. Nature 232:418-21.

Obled C, Arnal M, Fauconneau G. 1983. Whole-body threonine, leucine, tyrosine, lysine and histidine fluxes during post weaning development of the rat. Les
Colloques de l'INRA 16:23-7.

Schoeninger MJ, DeNiro MJ. 1984. Nitrogen and carbon isotopic composition of bone collagen from marine and terrestrial animals. Geochimica et Cosmochemica Acta 48:625-39.

Stuiver M, Polach HA. 1977. Discussion: reporting of ${ }^{14} \mathrm{C}$ data. Radiocarbon 19(2):355-63.

Tanaka H, Nakatomi Y, Takahashi K, Ogura M. 1991. Metabolism of lysine and tryptophan in growing rats at various dietary levels. Agricultural and Biological Chemistry 55:531-7.

Tieszen LL, Boutton TW, Tesdahl KG, Slade NA. 1983. Fractionation and turnover of stable carbon isotopes in animal tissues: implications for ${ }^{13} \mathrm{C}$ analysis of diet. Oecologia (Berlin) 57:32-7.

Yudkin M, Offord R. 1973. Comprehensible biochemistry. Sydney: Longman Group Limited. p 360, 382. 